\title{
HOMENAGEM AO DR. ANTÓNIO MACHADO GUERREIRO
}

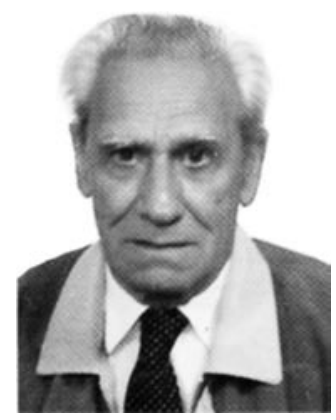

António Machado Guerreiro foi um dos primeiros funcionários do Centro de Estudos Geográficos. Encarregado das tarefas administrativas, acabou por trabalhar em tudo o que permitisse o funcionamento mais eficiente do Centro. Viveu os "tempos heróicos" da sua primeira fase, contribuiu para que fosse por diante o projecto que representava, apoiou o trabalho dos investigadores que, em número crescente, lá trabalhavam, acompanhou activamente o seu crescimento e diversificação. Sobre ele escrevia em 1980 Orlando Ribeiro, fundador do Centro e, durante décadas, o seu grande orientador científico: colaborou "primeiro como amanuense e depois a pouco e pouco como pau para toda a obra, pois tanto copiava um texto emaranhado, sugerindo correcções ou aclarações sempre pertinentes, como arranjava qualquer mecanismo que se avariasse - como ainda hoje, licenciado em Filologia Românica, autor de estudos etnográficos, continua a ser o mais dedicado e assíduo dos nossos colaboradores" (Finisterra, XV, 30, p. 243).

O Dr. Machado Guerreiro faleceu em Abril de 2007. Secretário durante anos desta revista, trabalhando minuciosamente, mesmo quando não figurava como tal, na sua organização e preparação, não podia a Finisterra deixar de lhe prestar, nesta altura, uma sentida, ainda que singela, homenagem. Incluem-se nas páginas que se seguem alguns depoimentos dos que com ele trabalharam, precedidos por uma notícia biobibliográfica preliminar. Os depoimentos reunidos testemunham eloquentemente o contributo que teve, na consolidação do Centro de Estudos Geográficos, este Homem simples, mas ao mesmo tempo inteligente e muito empenhado. 